\title{
T19 - Caracterización y evaluación de la calidad del agua de los ríos Quiscab y San Francisco, Guatemala
}

\author{
Norma E. Gil \\ Centro de Estudios del Mar y Acuicultura (CEMA), Universidad de San Carlos de Guatemala
}

*Autor al que se dirige la correspondencia: normadecastillo1965@yahoo.com

\section{Resumen}

T os ríos Quiscab y San Francisco son los principales afluentes del lago de Atitlán. Para determinar el aporte de _contaminación de estos ríos, se realizaron ocho muestreos durante dos años (septiembre 2011 a septiembre 2013), evaluando la parte alta, media y baja de las dos sub cuencas y desembocaduras en el lago de Atitlán. Se midieron los parámetros fisicoquímicos, calculando el Índice de Calidad del Agua (ICA) de El Salvador. Se evaluó la presencia y cantidad de macroinvertebrados acuáticos y se calculó el Indice Biológico por Familias de El Salvador (IBF-SV-2010). Se evaluó la presencia de fitoplancton en forma cualitativa y cuantitativa en la desembocadura de los ríos en el lago. Los dos ríos presentaron valores de ICA y de IBF-SV regular y regular pobre respectivamente. La contaminación del agua no reveló diferencias significativas entre las épocas de los años estudiados (invierno y verano, es decir seca y lluviosa). Se obtuvieron dos mapas en los que se observó que en las partes altas de ambas cuencas se mostraban valores aceptables de calidad del agua. Esta calidad se va deteriorando desde la parte media hasta la parte baja de los ríos, volviendo a mejorar en la desembocadura del lago de Atitlán. En los monitoreos cuantitativos de fitoplancton de la desembocadura de los ríos se observó una alta presencia de organismos representantes de Cianophytas, no existiendo diferencias en cuanto a cantidad y género en comparación con el invierno y verano.

Palabras claves: Calidad del agua, macroinvertebrados acuáticos, cianophytas

\section{Abstract}

$\mathrm{T}$ he Quiscab and San Francisco rivers are the main tributaries of Atitlan Lake. To determine the contribution of contamination of these rivers, eight samplings were perform two years (September 2011 to September 2013), evaluating the upper, middle and lower parts of the two sub-basins and the outlet of the lake, measuring the physicochemical parameters using the Water Quality Index from El Salvador (ICA in Spanish). The biological indicators were measured using aquatic macro invertebrates with the Biological Families Index from El Salvador (IBF-SV-2010) and phytoplankton in a qualitative and quantitative way only in the outlets of the rivers in the lake. The results of ICA to San Francisco River were lower in comparison to Quiscab River. The IBF-SV-2010 results of San Francisco River reported values of poor water quality and Quiscab River reported values of regular water quality. Two maps established that acceptable values of water quality are in the upper parts of both basins, which were deteriorating from the middle section to the bottom section of both rivers, improving at the entrance in Lake Atitlan. A practical manual was design with aquatic macroinvertebrates found in the work area used in situ, which allow field technicians to estimate a threshold level of contamination to prevent adverse effects, such as excessive growth of cyanobacteria. Quantitative monitoring of phytoplankton in the river outfall in the lake, reported high percentages of Cianophyte algae, no differences in terms of gender and quantity compared to the winter and summer seasons.

Keywords: Quality Index-ICA macroinvertebrates 